\title{
Initial sprout growth of potato seed minitubers under salt stress
}

\author{
Camilla Paulino de Oliveira ${ }^{1}$, Gabriel Zanuto Douradinho ${ }^{1}$, Guilherme Bortolazzo ${ }^{1}$, Fábio \\ Steiner $^{1}$
}

${ }^{1}$ Universidade Estadual de Mato Grosso do Sul - UEMS, Unidade Universitária de Cassilândia - UUC. Cassilândia, MS, Brasil.

E-mail: gabriel.douradinho@gmail.com; steiner@uems.br

Recebido: 10/10/2015; Aceito: 21/12/2015.

\begin{abstract}
Potato (Solanum tuberosum L.) is a major crop worldwide and the tuber yield of currently used cultivars is strongly reduced at high soil salt levels. The effects of salt stress on early sprout growth of potato plants were investigated using the cultivar Ágata. Potato seed minitubers were planted in $0.4 \mathrm{~L}$ pots filled with commercial substrate $\left(\right.$ Bioplant $^{\circledR}$ ), and maintained under greenhouse conditions. A completely randomized design with five treatments and five replications was used. Three days after sprouting, potato plants were exposed to five salinity levels [0 (control), 25, 50, 75 and $100 \mathrm{mmol} \mathrm{L}^{-1}$ of $\mathrm{NaCl}$ ] for 28 days. Results showed that the exposure of plants to $100 \mathrm{mmol} \mathrm{L}^{-1} \mathrm{NaCl}$ reduced the shoot height $(72 \%)$, shoot dry matter $(76 \%)$ and root dry matter $(75 \%)$ of potato plants compared to the $\mathrm{NaCl}$-free control. The length of longest roots was not affected by salinity levels, indicating that inhibition of shoot growth is more severe that of the root. The exposure to high salt concentrations severely restricted the early sprout growth of potato plants. Results of this study stated that salt-stress is a constraint on potato production, and the use of cultivars tolerant to salt stress can be a strategy to achieve high levels of potato tuber yield under salinity conditions.
\end{abstract}

Key words: Solanum tuberosum L., salinity, osmotic stress, $\mathrm{NaCl}$.

\section{Crescimento inicial de brotações de minitubérculos de batata em condições de estresse salino}

\section{RESUMO}

A batata (Solanum tuberosum L.) é uma das principais culturas a nível mundial e a produção de tubérculos das cultivares atualmente cultivadas pode ser severamente reduzida em condições de elevado níveis de salinidade do solo. Este estudo teve como objetivo avaliar os efeitos do estresse salino no crescimento inicial de brotações do cultivar de batata 'Ágata'. Minitubérculos de batata foram plantados em vasos plásticos de $0,4 \mathrm{~L}$ preenchidos com substrato comercial (Bioplant ${ }^{\circledR}$ ) e mantidos em casa-de-vegetação. O delineamento experimental utilizado foi o inteiramente casualizado com cinco tratamentos e cinco repetições. Três dias após a emergência, as plântulas foram expostas à cinco níveis de salinidade [0 (controle), 25, 50, 75 e $\left.100 \mathrm{mmol} \mathrm{L}^{-1} \mathrm{de} \mathrm{NaCl}\right]$, por 28 dias. A adição de $100 \mathrm{mmol} \mathrm{L}^{-1}$ de $\mathrm{NaCl}$ reduziu a altura das plantas (72\%), matéria seca da parte aérea (76\%) e a matéria seca das raízes $(75 \%)$ de batata em comparação das plantas sem exposição ao estresse salino. O comprimento das raízes de batata não foi afetado pelos diferentes níveis de salinidade, indicando que a inibição do crescimento da parte aérea é mais afetada que o crescimento das raízes. A exposição dos minitubérculos de batata a elevados níveis de salinidade reduziu severamente o crescimento inicial dos brotos de batata. Os resultados deste estudo sugerem que o estresse salino é uma restrição para a produção de batata, e a utilização de cultivares tolerantes à salinidade pode ser uma estratégia para obter altos índices de produtividade de tubérculos de batata sob condições de salinidade.

Palavras-chave: Solanum tuberosum L., salinidade, estresse osmótico, $\mathrm{NaCl}$. 


\section{Introduction}

The sustainability of agriculture production in many areas of the world including North and South America, Asia, Europe and Australia is at risk due to soil salinization (CHAVES et al., 2006). Salinity caused by excessive salts in the soil solution or in irrigation water is one of the major environmental stresses that limit plant growth and development in arid, semiarid and other areas of the world. One-third of the world's cultivated land, $7 \%$ of the total world land and $50 \%$ of the irrigated land is affected by salinity (ZHU, 2001). Salt-affected soil may be grouped into four categories based on the electrical conductivity of the extract (ECe) from the water saturated soil, i.e., slightly saline (ECe 2 to $4 \mathrm{dS} \mathrm{m}^{-1}$ ), moderately saline (ECe 4 to $8 \mathrm{dS} \mathrm{m}^{-1}$ ), highly saline (ECe 8 to $16 \mathrm{dS} \mathrm{m}^{-1}$ ) and extremely saline

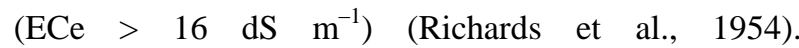
Conventionally, however, saline soils are defined as those having an ECe value $\geq 4 \mathrm{dS} \mathrm{m}^{-1}$ or $40 \mathrm{mmol} \mathrm{L}^{-1}$ of $\mathrm{NaCl}$.

Adverse effects of salt stress on plant growth are due to ionic imbalance, osmotic stress, specific ion toxicity, oxidative stress (MUNNS, 2002) and molecular disorders (MUNNS; TESTER, 2008). Salinity reduces cell turgor and depresses rates of root and leaf elongation (FRICKE et al., 2006), suggesting that environmental salinity acts primarily on water uptake. Excessive salt concentrations in the soil solution also changes the ability of plants to absorb, transport and utilize the nutrients needed for their growth and development (PARIDA; DAS, 2005; FEIJÃO et al., 2011). Nutritional imbalance caused by salinity is mainly due to the reduction of uptake and assimilation of essential nutrients by the plant such as nitrogen $(\mathrm{N})$, potassium (K) and calcium (Ca) (ZHU, 2001).

Salinity affects plant growth at all developmental stages; however, sensitivity varies from one growth stage to another. The sprout development is one of the most fundamental and vital phases in the growth cycle of plants that determine plant establishment and the tuber yield of the potatoes. Therefore, a greater salt stress tolerance could improve the plant establishment and potato yield in saline soils. However, the effects of salinity on sprout development and plant establishment of potato crop are incipient and inconclusive.

Ghosh et al. (2001) showed that the emergence was delayed, growth and dry matter production, especially in tubers, were depressed with the increase in the salt level. These authors found that salt stress decreased the total tuber yield due to the decrease in the tuber number per plant and average tuber weight. In general, the effect of salt stress on plants depends on the concentration and time of exposure of salt, plant genotypes and other environmental factors (PARIDA; DAS, 2005; MUNNS; TESTER, 2008; FEIJÃO et al., 2011).
Potato (Solanum tuberosum L.) is a major crop worldwide and the tuber yield of currently used cultivars is strongly reduced at high soil salt levels. Potato cultivation in many parts of the world is carried out in irrigated areas, and therefore subject to grow in salinity conditions due to inadequate irrigation management and application of saline water. The present study analyzes the effects of salt stress on early sprout growth of potato plants (Solanum tuberosum L., cv. Ágata) under greenhouse conditions.

\section{Material and Methods}

The experiment was conducted in a greenhouse at the Horticultural Department of the Mato Grosso do Sul State University, in Cassilândia, MS, Brazil (1905'20" $\mathrm{S}, 51^{\circ} 48^{\prime} 24^{\prime \prime} \mathrm{W}$, and altitude of $470 \mathrm{~m}$ ).

Basic potato seed minitubers of the cultivar Ágata were planted on April $24^{\text {th }}, 2015$, in plastic pots of $0.4 \mathrm{~L}$ filled with commercial substrate $\left(\right.$ Bioplant $\left.^{\circledR}\right)$. The experiment was arranged in a completely randomized design with five treatments and five replications (an individual pot containing one potato seed minitubers represented one replicate). Three days after sprouting, potato plants were exposed to five salinity levels [0 (control), 25, 50, 75 and $100 \mathrm{mmol} \mathrm{L}^{-1}$ of $\mathrm{NaCl}$. The different concentrations of $\mathrm{NaCl}$ solutions were applied to each pot daily to maintain the soil moisture level at $80 \%$ of field capacity and proper care was taken to prevent leaching of water. The seedlings were grow in the plant growth chamber with a photoperiod of $16 \mathrm{~h}$ of light, $8 \mathrm{~h}$ of darkness, light intensity of $40 \mu \mathrm{mol} \mathrm{m} \mathrm{m}^{-2} \mathrm{~s}^{-1}$ and temperature of $21^{\circ} \mathrm{C}\left( \pm 2{ }^{\circ} \mathrm{C}\right)$.

After $28^{\text {th }}$ day exposure to salt stress, all plants were harvested and separated into shoots and roots, dried in a forced air circulation oven for four days at $65^{\circ} \mathrm{C}$, and then weighed. The results were expressed in $\mathrm{mg}$ per seedling. The shoot and root length was measured using meter scale. The results were expressed in centimeter $(\mathrm{cm})$. From the data of total dry matter of plants, equation 1 was used to measure the yield stability index (YSI):

$$
\mathrm{YSI}=Y_{\mathrm{S}} / Y_{\mathrm{C}}
$$

where YSI is the yield stability index, $Y_{\mathrm{S}}$ is the total dry matter yield under drought stress (mg per plant) and $Y_{\mathrm{C}}$ is the total dry matter yield under ideal conditions (control) (BOUSLAMA;D SCHAPAUGH, 1984).

Data were submitted to analysis of polynomial regression, and significant equations (F test, $P \leq 0.05$ ) with the higher coefficient of determination were adjusted. All analyses were performed using SigmaPlot 11.0 software for Windows (Systat Software, Inc., San Jose, CA, USA).

Revista de Agricultura Neotropical, Cassilândia-MS, v. 3, n. 1, p. 7-11, jan./mar. 2016. 


\section{Results and Discussion}

The early growth of potato plants was negatively affected by the salinity levels (Figure 1). The shoot height was reduced from $22.3 \mathrm{~cm}$ in the control treatment $(\mathrm{NaCl}$-free) to a minimum of $6.3 \mathrm{~cm}$ when the plants were exposed to $100 \mathrm{mmol} \mathrm{L}^{-1} \mathrm{NaCl}$, indicating mean reduction of $72 \%$ (Figure 1A). Shoot dry matter reduced from $77.8 \mathrm{mg}$ per plant in the $\mathrm{NaCl}$-free control to a minimum of $18.3 \mathrm{mg}$ per plant with the addition of $100 \mathrm{mmol} \mathrm{L}^{-1} \mathrm{NaCl}$, indicating mean reduction of $76 \%$ (Figure 1C). One of the initial effects of salt stress on plant is the reduction of growth rate. Ghosh et al. (2001) reported that salinity decreases the growth and dry matter production of potato plants, and the electrical conductivity (ECe) of $1.95 \mathrm{dS} \mathrm{m}^{-1}$ decreased the total dry matter production at around of $68 \%$. In soybean [Glycine max (L.) Merrill.], Dolatabadian et al. (2011) reported that salinity stress significantly decreased shoot and root dry matter, plant height and leaf number. Excessive salt concentrations in the soil reduce the solution water potential, causing toxic effects and injuries and disorders in the metabolism of plants (MUNNS; TESTER, 2008). According to Delfine et al. (1999), under high salinity an irreversible impairment of the photosynthetic apparatus, associated with a reduction of ribulose-1,5-bisphosphate carboxylase/ oxygenase (Rubisco) activity, occurs when the stress is prolonged and salt continues to accumulate in the leaves.

Root dry matter of potato plants decreased progressively with increasing of $\mathrm{NaCl}$ levels (Figure 1D). Root dry matter was reduced from $66.3 \mathrm{mg}$ per plant in the $\mathrm{NaCl}$-free control to a minimum of $16.3 \mathrm{mg}$ per plant in the plants exposed to the higher salt treatment $\left(100 \mathrm{mmol} \mathrm{L}^{-1} \mathrm{NaCl}\right)$, reporting a decrease of $75 \%$. However, the length of longest roots was not affected by salinity levels (Figure 1B). These results indicate that increasing the salt concentrations in the solution resulted in potato roots with reduced thickness.

Some of the negative effects of salinity have been caused mainly by $\mathrm{Na}^{+}$and $\mathrm{Cl}^{-}$ions in plants and these ions produce the decisive conditions for plant survival by intercepting different plant mechanisms (MUNNS, 2002; PARIDA; DAS, 2005). Plant roots are generally affected due to $\mathrm{Na}^{+}$and $\mathrm{Cl}^{-}$along with other cations present in the soil solution in different concentration. However, the uptake of these ions depends on the plant growth stage, genetic characters and environmental factors like temperature, relative humidity and light intensity (PARIDA; DAS, 2005).
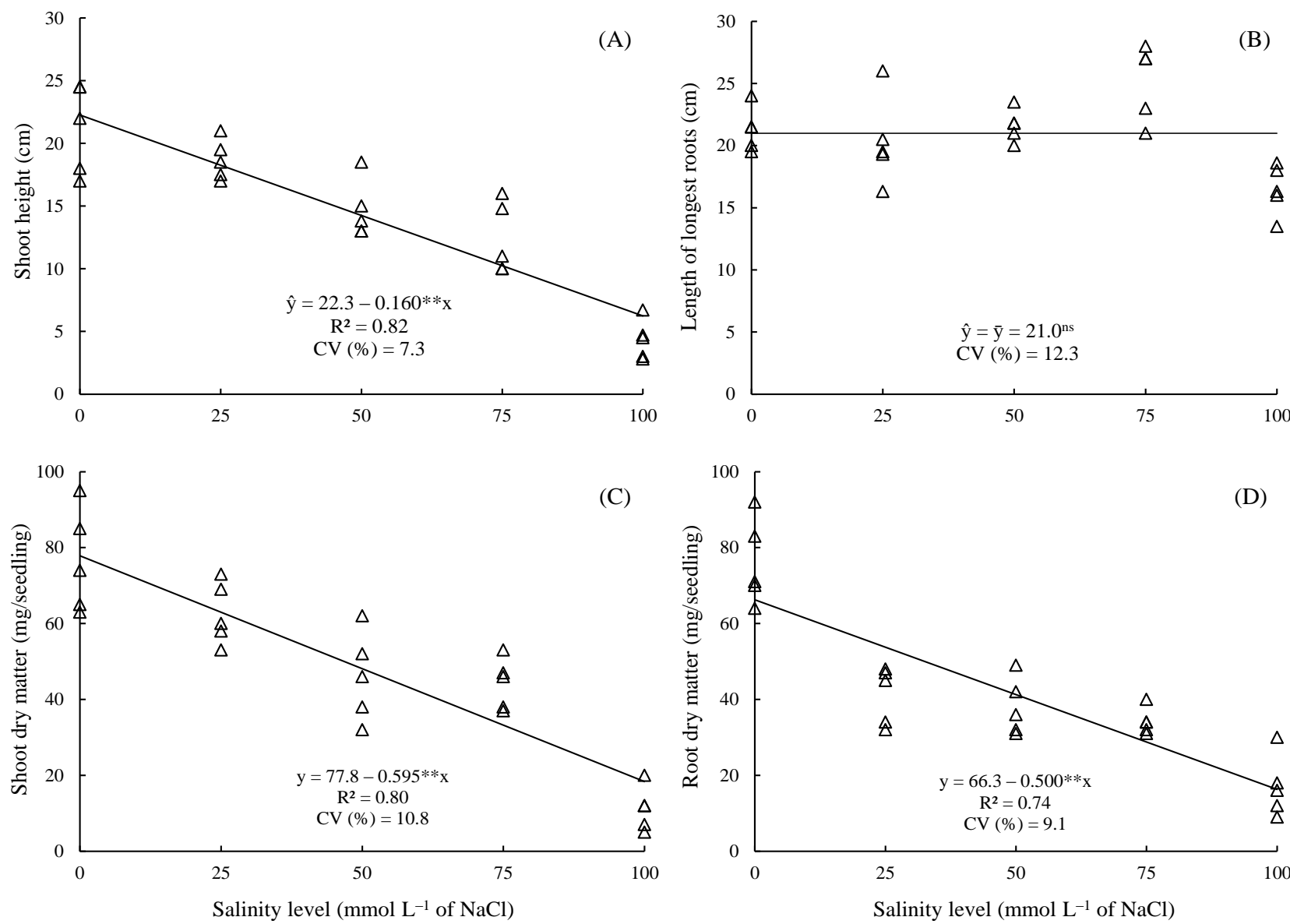

Figure 1. Effects of salt stress on the shoot height (A), length of longest roots (B), shoot dry matter (C) and root dry matter (D) of potato plants (Solanum tuberosum L., cv. Ágata). ${ }^{\mathrm{ns}}$ : not significant. $* *$ : statistical significance at 1\%. CV: coefficient of variation.

Revista de Agricultura Neotropical, Cassilândia-MS, v. 3, n. 1, p. 7-11, jan./mar. 2016. 
The yield stability index (YSI) of potato plants varied greatly depending on the salinity levels (Figure 2). Crop species have exhibited substantial differences in salt tolerance based on their relative yields. In general, the relative yield was drastically reduced when the potato plants were exposed to high salinity levels. When the yield stability index in response to addition of 25, 50, 75 and $100 \mathrm{mmol} \mathrm{L}^{-1} \mathrm{NaCl}$ is less than 1.0; 0.9; 0.7 and 0.50 the plant species is classified as moderately sensitive to salt tolerance (MASS, 1986). Therefore, results presented here suggest that potato is a moderately sensitive species to the negative effects of high salt levels during the seedling establishment stage, confirming the results reported by Ghosh et al. (2001). There are abundant literature indicating that plants are particularly susceptible to salinity during the seedling and early vegetative growth stage. The salinity delayed the sprouting of potato tubers and early sprout growth was depressed with the increase in the salt level (GHOSH et al., 2001).

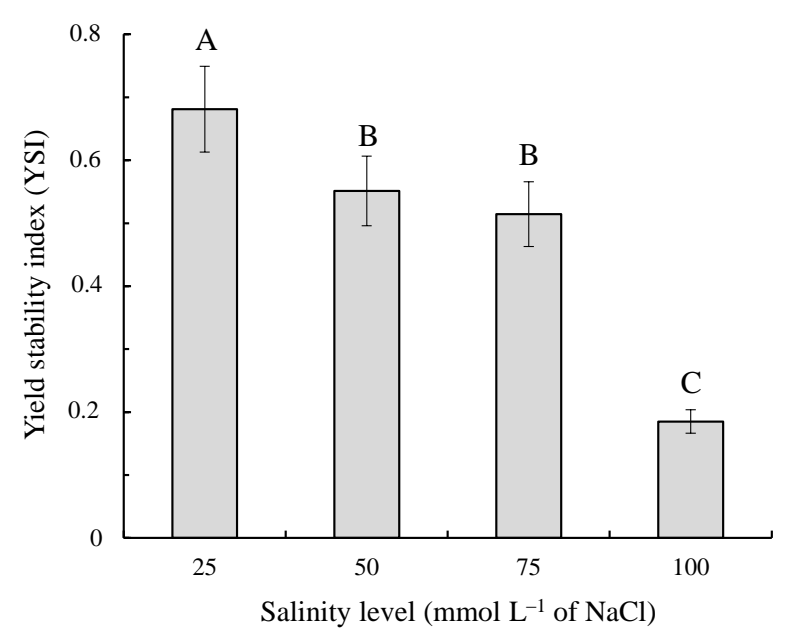

Figure 2. Effects of salt stress on the yield stability index (YSI) of potato plants (Solanum tuberosum L. cv. Ágata). Bars followed by the same letter are not significantly different by Tukey test at 0.05 level of confidence. Data refer to mean values $(n=5) \pm$ standard error.

The assimilate partitioning between roots and shoots of potato plants are shown in Figure 3. The slight increase in dry matter production of shoots in the plants exposed to low salt concentrations may be due to the lower dry matter partitioning to the roots (Figure 3). These results indicated that the partitioning of assimilates to roots might be affected by salinity. Assimilate partitioning is a complicated process that can be controlled simultaneously by sources and sinks. In general, plants exposed to high salinity levels often partition photosynthate occurs preferentially to the roots, thereby maintaining a balance between processes required in roots (e.g.; water and nutrient uptake) and those required in shoots (e.g., photosynthesis). These results were verified using the $100 \mathrm{mmol} \mathrm{L}^{-1} \mathrm{NaCl}$ concentration, where there was a greater partition assimilated in potato roots.

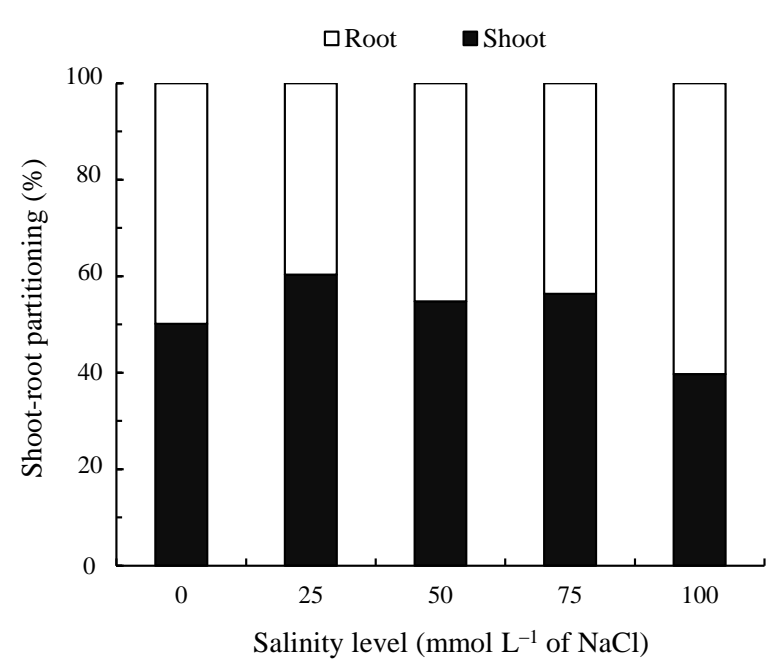

Figure 3. Effects of salt stress on assimilate partitioning between roots and shoots of potato plants (Solanum tuberosum L., cv. Ágata).

\section{Conclusions}

Salt stress severely restricted the early sprout growth of potato plants, while the length of longest roots is not affected by salinity, indicating that inhibition of shoot growth is more severe that of the root.

Potato is a moderately sensitive species to high salt concentrations during the seedling establishment stage, and the use of cultivars tolerant to salt stress can be a strategy to achieve high levels of potato tuber yield under salinity conditions.

\section{References}

BOUSLAMA, M. SCHAPAUGH, W. T. Stress tolerance in soybean. Part. 1: Evaluation of three screening techniques for heat and drought tolerance. Crop Science, Madison-USA, v. 24, n. 5, p. 933-937, 1984.

CHAVES, L. C. G.; ANDRADE, E. M.; CRISOSTOMO, L. A.; NESS, R. L. L.; LOPES, J. F. B. Risk of degradation in irrigated soil at the distrito de irrigação do perímetro Araras Norte, Ceará, Brazil. Revista de Ciências Agronômicas, Natal-CE, v. 37, n. 3, p. 293-299, 2006.

DELFINE, S.; ALVINO, A.; VILLANI, M. C.; LORETO, F. Restrictions to carbon dioxide conductance and photosynthesis in spinach leaves recovering from salt stress. Plant Physiology, Rockville-USA, v. 119, p. 1101-1106, 1999.

DOLATABADIAN, A.; MODARRESSANAVY, S. A. M.; GHANATI, F. Effect of salinity on growth, xylem structure and anatomical characteristics of soybean. Notulae Scientia Biologicae, Romania-RO, v. 3, p. 41-45, 2011.

FEIJÃO, A.R.; SILVA, J.C.B.; MARQUES, E.C.; PRISCO, J.T.; GOMES-FILHO, E. Efeito da nutrição de nitrato na 
tolerância de plantas de sorgo sudão à salinidade. Revista Ciência Agronômica, Natal-CE, v. 42, n. 3, p. 675-683, 2011.

FRICKE, W.; AKHIYAROVA, G.; WEI, W.X.; ALEXANDERSSON, E.; MILLER, A.; KJELLBON, P.O.; RICHARDSON, A.; WOJCIECHOWSKI, T.; SCHEIBER, L.; VESELOV, D.; KUDOYAROVA, G.; VOLKOV, V. The short-term growth response to salt of the developing barley leaf. Journal of Experimental Botany, Oxford-UK, v. 57, n. 6, p. 1079-1095, 2006.

GHOSH, S. C.; ASANUMA, K.; KUSUTANI, A.; TOYOTA, M. Effect of salt stress on some chemical components and yield of potato. Soil Science and Plant Nutrition, Tokio-JP, v. 47 , n. 3, p. $467-475,2001$.

MASS, E. V. Salt tolerance of plants. Applied Agricultural Research, Okla-MY, v. 1, n. 1, p.12-26, 1986
MUNNS, R. Comparative physiology of salt and water stress. Plant, Cell and Environment, Malden-USA, v. 25, n. 2, p. 239-250, 2002.

MUNNS, R.; TESTER, M. Mechanisms of salinity tolerance. Annual Review of Plant Biology, Palo Alto-USA, v. 59, n. 7, p. 651-681, 2008.

PARIDA, A.K.; DAS, A.B. Salt tolerance and salinity effects on plants: a review. Ecotoxicology and Environmental Safety, New York-USA, v. 60, n. 6, p. 324-349, 2005.

RICHARDS, L.A. Diagnosis and improvement of saline and alkali soils. Washington DC: United States Department of Agriculture. 1954. 160p. (Handbook no. 60).

ZHU, J. K. Plant salt tolerance. Trends in Plant Science, Oxford-UK, v. 6, n. 2, p. 66-71, 2001. 